ОСОБЛИВОСТІ ВОКАЛЬНОЇ ПІДГОТОВКИ МАЙБУТНІХ УЧИТЕЛІВ МУЗИЧНОГО МИСТЕЦТВА ЗАСОБАМИ ФОРМУВАННЯ ІМПЕДАНСУ ЯК ОСНОВНОГО ЗАХИСНОГО МЕХАНІЗМУ ГОЛОСОВОЇ ФУНКЦІЇ

\title{
PECULIARITIES OF THE FUTURE MUSIC TEACHERS' VOCAL TRAINING BY MEANS OF THE IMPEDANCE FORMATION AS A BASIC PROTECTIVE MECHANISM OF THE VOICE FUNCTION
}

УДК 37. $011.3-051: 784.9$

DOI https://doi.org/10.32843/2663-

$6085 / 2019.21 .2-36$

\section{Павлічук B.I.,}

викладач-методист

Луцького педагогічного коледжу

Чайка В.А.

викладач вокалу

Луцького педагогічного коледжу
Статтю присвячено висвітленню загальнопедагогічних і методично-організаційних особливостей соормування вокальної майстерності майбутніх учителів музичного мистецтва у процесі професійної підготовки. Доцільність обраної теми підсилюється низкою суперечностей і неусталеністю різноманітних прийомів постановки голосу, які виникли у процесі довготривалого періоду еволюційного розвитку класичної вокальної школи. Як наслідок, вокальнометодичні прийоми фрормування співацького голосу є надзвичайно багатогранними та різноманітними.

Теоретична новизна дослідження зумовлюється необхідністю пошуку нових організаційних форм, методів і прийомів вокальної педагогіки для ефективного виявлення й оволодіння саме такими вокальними техніками, які б максимально впливали на розвиток вокальних здібностей співаків-початківців, допомагали їм у майбутній професійній діяльності. У дослідженні проаналізовано деякі аспекти вокальних технік як захисних систем механізму голосової ффункції педагога-вокаліста. Теоретично обгрунтовано взаємодію трьох компонентів у процесі вокальної підготовки: постановка дихання, гортані та резонаторів як джерел якісного звукоутворення. Доведено непересічне значення явища імпедансу в процесі фронації та з'ясовано, що техніка співу із сильним імпедансом є найдоцільнішою у навчанні постановки голосу майбутніх учителів музичного мистецтва.

Формування готовності майбутнього педагога до музично-виховної діяльності у школі передбачає озброєння його передовими та грунтовними сраховими знаннями, адже важливим елементом підготовки вчителя сучасної школи є сформованість високого рівня виконавських умінь $і$ навичок, повне розкриття творчого потенціалу, готовність знайомити дітей зі світом музичного мистецтва, залучаючи їх до музикування. Одним $з$ основних компонентів фрахової підготовки майбутнього вчителя музичного мистецтва є вокальна підготовка, тому що саме спів є основним видом діяльності учнів на уроках.
Ключові слова: професійна підготовка майбутнього вчителя музичного мистецтва, вокальна майстерність, вокальна техніка, імпеданс, формування виконавських умінь.

The article is devoted to the coverage of general pedagogical, methodological and organizational features of the future music teachers' vocal skills forming in the vocal training process. The practicality of the chosen theme is enhanced by a number of contradictions and instability of various techniques of staging that emerged during the long period of evolutionary development of the classical vocal school. Consequently, the vocal and methodical techniques of forming a singing voice are extremely diverse and varied.

The theoretical novelty of the study is caused by the necessity of searching the innovative organizational forms, methods and techniques of vocal pedagogy in aim to effectively identify and master such vocal techniques that would maximally influence the development of vocal abilities of novice singers, assist them in their future professional activity. The study analyzes some aspects of vocal techniques as protective systems of a teacher's vocal function mechanism. The interaction of three components in the process of vocal training is theoretically substantiated: breathing, larynx, and resonators as sources of high-quality sound. The unprecedented importance of the impedance phenomenon in the phonation process is proved and it is found that the technique of singing with strong impedance is the most expedient in training the voice of future music teachers.

Formation of the future teachers' readiness for music-educational activity at a school involves equipping them with advanced professional knowledge. An important component of the teacher preparation for the modern school is the formation of a high level of performing skills, full disclosure of creativity with the potential of creativity to music. Vocal training is one of the main components of the professional training of a future music teacher, because singing is the main activity of students at Music lessons.

Key words: future Music Art teachers professional training, vocal skills, vocal technique, impedance, performing skills training.
Постановка проблеми у загальному вигляді. Сучасні тенденції розвитку суспільства й освіти України вимагають якісно нової системи підготовки майбутніх педагогічних кадрів. Актуальним $€$ удосконалення та впровадження у зміст навчання й у практику роботи вищої школи новітніх методик навчання, які сприяють якості й ефективності засвоєння знань. На необхідності та важливості змін у підходах до розв'язання завдань, поставлених перед вищою мистецько-педагогічною освітою, наголошують Є. Антонович, В. Бутенко,
Л. Масол, Н. Миропольська, О. Олексюк, В. Орлов, Г. Падалка, О. Рудницька та ін.

Формування готовності майбутнього педагога до музично-виховної діяльності у школі передбачає озброєння його передовими та ґрунтовними фаховими знаннями, адже важливим елементом підготовки вчителя сучасної школи є сорормованість високого рівня виконавських умінь і навичок, повне розкриття творчого потенціалу, готовність знайомити дітей зі світом музичного мистецтва, залучаючи їх до музикування. Одним 3 основних 
компонентів фрахової підготовки майбутнього вчителя музичного мистецтва $€$ вокальна підготовка, тому що саме спів є основним видом діяльності учнів на уроках.

На думку Л. Василенка, вокальна підготовка студентів музично-педагогічних фракультетів - це процес, спрямований на максимальний розвиток у них здатності до глибокого розуміння музичних образів і втілення їх у досконалій співацько-виконавській фрормі, усвідомлення студентами ролі співу в системі життєдіяльності, загальнокультурного і музичного розвитку особистості, а також вироблення у майбутніх вчителів умінь застосовувати методи й організаційні фрорми, адекватні завданням вокального навчання учнів [2, с. 9].

Натомість Н. Ройтенко розглядає вокальну підготовку як цілісну складну систему, що є сукупністю різних складників: суб'єктів, об'єктів, структури, методики, етапів розвитку, а також різноманіття зв'язків між ними [9, с. 101].

Саме тому в умовах глобалізації поліжанровості музичного мистецтва важливим для майбутнього вчителя $є$ знання і володіння різними вокальними техніками, щоб вміло та на високому профресійному рівні демонструвати твори мистецтва. Для досягнення максимального засвоєння спеціальних знань, умінь і навичок потрібно пам'ятати про синтез навчально-методичного матеріалу з індивідуальною практичною фрормою навчання постановки голосу.

Сучасні наукові дослідження в галузі вокальнометодичної підготовки майбутнього вчителя музичного мистецтва розглядали у своїх працях Л. Василенко, Л. Каменецька, Л. Гавриленко, О. Прядко. Формування вокально-звукової культури та розвиток вокального слуху висвітлено у працях О. Маруфенко та Т. Ткаченко. Значення акустики та ролі імпедансу здійснено у працях Л. Дмітрієва, В. Морозова, А. Рудакова, Р. Юссона.

Проте актуальним залишається пошук нових організаційних фрорм, методів і прийомів вокальної педагогіки для ефективного виявлення й оволодіння саме такими вокальними техніками, які б максимально впливали на розвиток вокальних здібностей співаків-початківців, допомагали їм у майбутній професійній діяльності.

Аналіз останніх джерел і публікацій. Проблемі професійної спрямованості у викладанні музичних дисциплін присвячено низку праць, які розкривають специфріку та вимоги підготовки спеціалістів на музично-педагогічних фракультетах, зокрема: теоретичні концепції профресійної підготовки вчителя музичного мистецтва (А. Манебені, Л. Воєводіна, Л. Горюнова, Л. Коваль, В. Крицький, Г. Падалка, Г. Пипін, О. Щолокова); профресійної підготовки майбутнього вчителя до музично-педагогічної діяльності (А. Болгарський, Н. Мозгальова, Т. Жигінас, О. Плохотнюк).
У науково-методичній літературі питання вокальної підготовки розглядається в різних аспектах, зокрема: теоретичні засади методики постановки голосу розглядають у свої працях Р. Юссон, Л. Дмітрієв, В. Морозов, М. Микиша, А. Заседателєв, Л. Работнов, Д. Аспелунд, А. Зданович та ін.; специоріка вокального виконавства та вокальної методики - О. Стахевич, Ю. Юцевич; інноваційні технології розвитку професійних рис студентів у процесі вокальної підготовки - Л. Лабінцева, Г. Панченко.

Виділення невирішених раніше частин загальної проблеми. Аналіз останніх наукових джерел засвідчує зростання інтересу до вокальнопедагогічної підготовки майбутнього вчителя музичного мистецтва.

Доцільність обраної теми підсилюється низкою суперечностей і заплутаних прийомів постановки голосу, які виникли у процесі довготривалого періоду еволюційного розвитку класичної вокальної школи. Як наслідок, вокально-методичні прийоми формування співацького голосу $€$ надзвичайно багатогранними та різноманітними.

Саме тому у процесі підготовки до вокальнопедагогічної діяльності викладач має не лише навчити студента володіти вокальними навичками, але й визначати шляхи, методи організації навчального процесу у загальноосвітній школі, прийоми та методи розвитку вокальних навичок у дітей. Адже завдяки співу у школярів збагачується не лише емоційна та культурна сорери, але, найголовніше, фрормується духовна складова частина особистості, що і є основним завданням педагогічної діяльності.

Проблема захисних механізмів голосової функції досі лишається актуальною, адже людський голос - це тендітний інструмент, який потребує дбайливого, вмілого використання та захисту.

3'ясування та розкриття низки питань, які, на нашу думку, недостатньо висвітлюються педагогами на заняттях із постановки голосу, визначають актуальність цієї статті.

Мета статті. На основі аналізу науково-педагогічного дискурсу розкрити загально-педагогічні та методично-організаційні особливості вокальної підготовки майбутніх учителів музичного мистецтва засобами фрормування імпедансу як основного захисного механізму голосової функції.

Виклад основного матеріалу. Освітні реалії, спричинені інтенсивним розвитком науки, новітніх інфрормаційних технологій, характеризуються тим, що вокально-виконавська практика залишається одним небагатьох видів мистецтва, в якому використовуються здебільшого емпіричні методи та прийоми. Це призводить до низки суперечностей між традиційними методами роботи у процесі профресійної підготовки майбутніх учителів музичного мистецтва. 
Варто зазначити, що для якісного опанування предмету «постановки голосу» існує комплекс вокально-технічних вимог, які повинні бути доступними у розумінні для подальшого використання на практиці майбутнім вчителем музичного мистецтва. Сучасна дослідниця Л. Антонова наголошує на тому, що уроки, які зараз пропонуються у середніх і закладах вищої освіти, переважно засновані на дистанційному принципі та мають чимало негативних наслідків [1. с. 70-74].

Існує дуже багато різноманітних типів вокальної техніки, їх характеризують за різноманітними критеріями та фрізіологічними ознаками. Вокальна техніка - це комплекс умінь і навичок, необхідних для усвідомленого управління фронаційним процесом для досягнення максимального акустичного есректу, що створює відповідну співочу ефрективність щодо діапазону та тембру за мінімальних енергетичних витрат співака [6, с. 152].

Спираючись на дослідження фрранцузького вченого, фоніатора Р. Юссона, пропонуємо розглянути такі три основні, на нашу думку, типи вокальної техніки:

- тип вокальної техніки зі слабким імпедансом;

- тип вокальної техніки із сильним імпедансом;

- назалізований тип вокальної техніки 3 надсильним імпедансом.

Більш детально розглянемо поняття імпедансу. Термін «імпеданс» походить від латинського impedio (перешкоджати) й означає комплексний опір. Відповідно, акустичний імпеданс - комплексний акустичний опір - це створення зворотного опору в надставній трубці співака, що веде до встановлення взаємозв'язаної системи коливань резонаторів і голосових складок і $€$ найважливішим акустичним механізмом у роботі голосового апарату, який дозволяє за порівняно малих затрат енергії отримувати надзвичайно великий акустичний ефект [12, с. 98-99].

Найдоцільнішим у співі вважається сильний імпеданс, що створюється рупором на рівні гортані, де майже повністю урівноважуються підскладковий тиск повітря та надскладковий опір. Це є надзвичайно потужним захисним механізмом голосових складок під час фронації, тоді як надсильний чи слабкий імпеданс діють у зворотному напрямку.

При надсильному імпедансі виникає занадто активне перевантажене дихання. Збільшення розходу повітря викликає реакцію пристосування дихальних механізмів: більш глибокий вдих і посилена робота видихальної мускулатури при одночасному збільшенні підскладкового тиску $[12$, с. 98]. Тобто імпеданс досягає такого високого рівня, що стає перешкодою нормальному функціонуванню складок і, як наслідок, виникає крикливий фрорсований звук.

Відповідно, слабкий імпеданс характеризується недостатньою роботою дихальної системи, недо- статньою опорою звуку, де навантаження повністю йде на гортань і голосові складки, що веде до швидкої втоми голосового апарату та втрати важливих характеристик звуку - природного вібратор, тембру, рівності звуковедення тощо. 3 цього зрозуміло, наскільки функція гортані тісно пов'язана з диханням у процесі звукоутворення, і неможливо розглядати одну окремо від іншої [5, с. 141].

Вчений Ф. Засєдатєлєв у своїх працях дотримується трьох основних компонентів постановки голосу: постановки дихання, гортані та резонаторів [3, с. 171]. Він стверджує, що правильна взаємодія дихання та роботи голосових зв'язок нерозривно пов'язана з потрібним розширенням гортані при співі, де й утворюється імпеданс [11, с. 48].

3 вищесказаного видно, що результатом повноцінного звукоутворення в контексті дихання $€$ дві обов'язкові умови - це опора звуку й опора дихання, які є головними компонентами співацької опори.

Л. Дмітрієв конкретизує систему утворення імпедансу та визначає співацьку опору як найважливіше відчуття для співака, завдяки якому він вільно і легко може володіти своїм голосом [5, с. 290]. Вчений пояснює це тим, що відчуття опертості звуку завжди супроводжується сильним скороченням гортанного сорінктера на рівні входу в гортань. Надзв'язкова порожнина гортані завжди відділена яскраво вираженим звуженням від порожнини глотки. Це звуження утворює у глотці т. зв. передрупорну камеру, саме в якій і виникає додаткова протидія - імпеданс [5, с. 294]. За таких умов голосові м'язи можуть проявляти максимум фрізіологічних можливостей у плані діапазону, теситури, сили звуку, зміні тембру голосу та загальної витривалості.

Цікаво відзначити і той фракт, що при піднятій і звуженій гортані досягнути імпедансу неможливо. Сам процес при правильному опусканні гортані вниз веде до звуження входу в гортань надгортанником, який прогинається. Саме тому педагогу важливо стежити за низьким положенням гортані співака-початківця. Адже при недостатньо опущеній гортані вхід до неї відкриється, порушиться механізм опори звуку та імпедансу, що приведе до опори на голосові складки.

Спираючись на дослідження Л. Дмітрієва, вчений, психолог, фрізіолог В. Морозов, який досліджував акустичні аспекти голосу, доводить, що така надгортанна порожнина виконує роль своєрідного резонатору високих частот і веде до вибіркового посилення спектральної енергії в полосі високої співацької фрорманти [8, с. 32]. Такої думки у своїх дослідженнях дотримувався і вчений Є. Рудаков.

Таким чином, ми можемо бачити важливість роботи над таким аспектом, як утворення імпедансу при співі. Адже часто викладачі з постановки голосу нехтують цим, що в окремих випадках 
може призвести до серйозних негативних наслідків. Нерідко трапляється і так, що у процесі роботи зі студентом, котрий потребує більших зусиль для оволодіння вокальною технікою, «відкривається» доволі профресійне звучання голосу. Це характеризується саме тим, що в співака-початківця з'являється відчуття співацької опори.

Звідси випливає, що:

а) величина імпедансу залежить від всіх ротоглоткових установок - рівень гортані, положення язика, положення м'якого піднебіння, фрорми розкриття рота і навіть, якоюсь мірою, від акустичних особливостей приміщення;

б) імпеданс визначає тонус змикання голосових складок і першочерговий гортанний спектр, дихальні пристосування, підскладковий тиск і звуковий тиск у ротоглоточному рупорі.

Повертаючись до поняття вокальної техніки і спираючись на вищесказане, ми виділяємо такі основні, на нашу думку, критерії для ії̈ класифрікації:

- особливості вокально-тілесних схем, якіє характерними для певного типу вокальної техніки;

- локалізацію внутрішніх відчуттів (м'язових відчуттів);

- акустичні ознаки (вокальний тембр, дзвінкість, силу та гнучкість голосу) [12, с. 158-159].

Висновки. Отже, ми можемо 3 упевненістю сказати, що однією 3 найважливіших і необхідних умов виховання голосу в процесі фрахової підготовки майбутнього вчителя музичного мистецтва $€$ знаходження сильного імпедансу, який дозволяє отримувати надзвичайно великий акустичний есрект за мінімальних фрізичних затрат. Адже фронація повинна утворюватися за більш сприятливих умов, що залежать від способу звуковидобування співака.

Якщо професійні співаки добре знають, як користуватися голосом, то серед початківців часто існує думка, що краса співу - в силі та потужності голосу, наслідком чого може стати фрорсування, крик і недбайливе ставлення до свого інструменту, що може привести до фратальних наслідків.

Саме зацікавленість теоретичними, науковометодичними питаннями вокально-виконавської культури, накопичування багажу знань біофрізики та психотехніки співацького процесу з боку як викладача, так і студента переводять вокальну методику з парадоксів, які не можна пояснити, у сореру завдань, що вирішуються на практиці.

\section{БІБЛІОГРАФІЧНИЙ СПИСОК:}

1. Антонова Л.В. Методика обучения студентов академическому пению: история и проблемы исследования. Поволжский педагогический вестник. 2014. № 3 (4). С. 70-74.

2. Василенко Л.М. Взаємодія вокального і методичного компонентів у процесі просресійної підготовки майбутнього вчителя музики : автореф. дис. ... канд. пед. наук : 13.00.02. Київ, 2003. 20 с.

3. Вопросы вокальной педагогики. Вып. IV / сост. и общ. ред. В.Л. Чаплина. Москва : Изд. «Музыка»,1969. 230 с.

4. Гроув Д. Музыкальный словарь Гроува (The Grove concise Dictionary of Music / Edited by Stanley Sadie. Assistant Editor Alison Latham. "Macmillan") ; пер. с англ., ред. и доп. Л.О. Акопяна. Москва : Практика, 2001.

5. Дмитриев Л. Основы вокальной методики. Москва : Музыка, 2007. 368 с.

6. Кушка Я.С. Методика навчання співу : навчальний посібник. Тернопіль : Навчальна книга. Богдан, 2013. 288 с.

7. Манебени А.Г. Методика обучения сольному пению : учебное пособие. Москва : Просвещение, 1987. 95 c.

8. Морозов В.П. Биофизические основы вокальной речи. Ленинград : «Наука», 1977. 232 с.

9. Ройтенко Н.О. Концептуальні засади педагогічного супроводу вокального розвитку майбутніх учителів музичного мистецтва. Наукові записки. Серія : Педагогічні науки. КДПУ ім. В. Винниченка. 2017. № 155. С. 101-104.

10. Чаплин В.Л. Физиологические основы фрормирования певческого голоса в аспекте регистровой приспособляемости. Москва : Издательство «ИнорормБюро», 2009. 180 с.

11. Юдин С.П. Формирование голоса певца. Москва : Государственное музыкальное издательство, 1962. 166 с.

12. Юссон Р. Певческий голос. Исследование основных фризиологических и акустических явлений певческого голоса. Москва : Изд. «Музыка», 1974. $258 \mathrm{c}$ 